\title{
Capillary Electrophoresis/Tandem Mass Spectrometry for Analysis of Proteins from Two-dimensional Sodium Dodecyl Sulfate Polyacrylamide Gel Electrophoresis
}

\author{
Xiaoying Jin ${ }^{1}$, Yajuan Chen ${ }^{1}$, David M. Lubman ${ }^{1}$, David Misek ${ }^{2}$ and Samir M. Hanash ${ }^{2}$ \\ ${ }^{1}$ Department of Chemistry, University of Michigan, Ann Arbor, MI 48109, USA \\ ${ }^{2}$ Department of Pediatrics and Common Diseases, School of Medicine, University of Michigan, Ann Arbor, MI 48109, USA
}

SPONSOR REFEREE: Dr. Terry Lee, Division of Immunology, Beckmann Research Institute of the City of Hope, Duarte, CA 91010-3000, USA

\begin{abstract}
Capillary electrophoresis/time-of-flight mass spectrometry(CE/TOFMS) has been used for analysis of in-gel digests of protein spots excised from two-dimensional sodium dodecyl sulfate polyacrylamide gel electrophoresis (2-D SDS-PAGE). An off-line purification and preconcentration procedure with a Zip Tip is used before CE/TOFMS analysis which allows for detection of protein spots with $<1$ picomole of material from 2-D gels. The off-line procedure provides sufficient purification for analysis while maintaining the quality of the $\mathrm{CE}$ separation. Using this procedure, several proteins from Coomassie Blue and zinc negatively stained gels are identified by the peptide maps generated and database searching. CE/TOF tandem mass spectrometry is used for the confirmation of database searching results and structural analysis of peptides that do not match the expected peptide maps obtained from the database in order to identify structural modifications. Several modifications were pinpointed and identified by this method. Copyright (C) 1999 John Wiley \& Sons, Ltd.
\end{abstract}

Received 4 October 1999; Accepted 5 October 1999

Two-dimensional (2-D) gel electrophoresis has become an essential tool for the study of the protein content of a cell. This method can resolve thousands of proteins in cell lysates based upon separation along a $\mathrm{pH}$ gradient in one dimension followed by an electrophoretic separation, which is related to the molecular weight in a second dimension. 2-D gel electrophoresis has become a convenient method for the study of protein synthesis regulation in normal and tumor cells and as a means for detection of the differential expression of proteins in response to external cell stimuli. The recent development of mass spectrometry based peptide mapping methods combined with database searching has resulted in a means for rapid identification of proteins from 2-D gel separations. ${ }^{1-14}$

Matrix-assisted laser desorption/ionization mass spectrometry (MALDI-MS) and liquid chromatography/mass spectrometry (LC/MS) have become methods for analysis of proteins separated by 2-D gel electrophoresis. Proteins are digested with an enzyme either via in-gel digestion or by being electroblotted onto a membrane for on-membrane digestion. MALDI-MS can provide identification based upon the peptide maps generated and the match obtained against a database. However, often a limited coverage of the protein sequence is obtained due to suppression effects in

\footnotetext{
*Correspondence to: David M. Lubman, Department of Chemistry, University of Michigan, Ann Arbor, MI 48109-1055, USA.

Contract/grant sponsor: National Institutes of Health; Contract/grant number: 2-R01GM49500-5.

Contract/grant sponsor: National Science Foundation; Contract/grant
} number: BIR-9513878. the MALDI-MS process, which is highly dependent on sample preparation. HPLC/MS has been used as an alternative for protein identification based upon peptide mapping, ${ }^{7}$ the sequence tag method ${ }^{14}$ and correlation of peptide fragmentation data with a database using the SEQUEST method. ${ }^{15}$ HPLC/MS provides a much more extensive coverage of the protein sequence by elimination of suppression effects and MS/MS structural information can be obtained using an ion trap or quadrupole mass spectrometer.

An alternative method for analysis of protein spots from 2-D gel separations is capillary electrophoresis mass spectrometry (CE/MS). ${ }^{16}$ Capillary electrophoresis can provide much improved resolution of peaks in complex mixtures in a much shorter time than HPLC. A CE separation of a tryptic digest can be performed in 510 min compared to $30-40 \mathrm{~min}$ for an equivalent HPLC separation, although in recent work Lee and co-workers have developed a novel integrated microscale LC column electrospray ionization (ESI) interface and variable flow solvent delivery system so that digests of gel-separated proteins can be analyzed in $<10$ min. ${ }^{17}$ In addition, CE consumes only nanoliter amounts of sample which is important when dealing with limited amounts of material from 2-D gel electrophoresis. The concentrated bands generated by the high resolution and the slow flow rate make CE ideal for high sensitivity in detection by mass spectrometry, which is a concentration dependent detector. Recently time-of-flight (TOF) mass analyzers have become popular for CE since CE/TOF can achieve a high duty cycle due to its nonscanning properties. ${ }^{18-24}$ 
The main disadvantage of CE relative to capillary HPLC for analysis of peptide digests from 2-D gel separations is the lack of preconcentration in the CE separation, which limits the concentration detection capabilites. The volume of a $50 \mathrm{~cm}$ long capillary with $50 \mu \mathrm{m}$ i.d. is about $1 \mu \mathrm{L}$. Since the optimal analyte resolution and separation efficiency are achieved with less than $2 \%$ of the total capillary column, the amount of sample injected into a $50 \mathrm{~cm}, 50 \mu \mathrm{m}$ i.d. capillary will be less than $20 \mathrm{~nL}$. Several approaches have been developed to increase the amount of sample injected onto the CE separation. On-column isotachophoresis (ITP), ${ }^{25}$ sample stacking, ${ }^{26}$ and field amplified polarity switching ${ }^{27}$ have been used to obtain a preconcentration factor of 100 . In other work, ${ }^{28}$ on-line coupling capillary ITP has been used to achieve a concentration factor of 1000 .

A second problem in the use of $\mathrm{CE}$ for analysis of protein digests from 2-D gels is that $\mathrm{CE}$ requires sample cleanup prior to injection. Complex samples containing salts and detergents lower the sensitivity and affect the CE separation. Solid phase extraction devices have been used for sample cleanup and preconcentration. Several groups have used an on-line coupling preconcentrator with an impregnated membrane, ${ }^{29}$ or a mini-column packed with reversed phase absorbent. ${ }^{16,30}$ Recently, the inlet of a capillary packed with $\mathrm{C}_{18}$ has been used to achieve sample stacking and cleanup. ${ }^{31}$ Although these methods improve the preconcentration of the sample, the nonhomogenous solid phase and high organic content of eluting solvent degrades the separation.

In this work, we use off-line solid phase extraction with CE/TOFMS to identify 2-D gel-separated proteins from cancer cell lines. The in-gel protein digest is cleaned with a commercial ZipTip $\mathrm{C}_{18}$ (Millipore) for $\mathrm{CE}$ analysis. In this off-line procedure, the sample is reconstituted from the ZipTip in a couple of microliters of deionized water where the preconcentration effect is achieved by minimizing the final sample volume. It is shown that protein digests can be detected from femtomole levels of material injected and that a relatively broad coverage of the protein sequence can be obtained. The use of the off-line purification method maintains the high resolution of the CE separation, which is especially important in cases where on-line MS/MS may be required for further detailed structural analysis.

\section{EXPERIMENTAL}

\section{D PAGE}

Proteins from Esophageal Adenocarcinoma and Thymocyte cell extracts were separated by 2-D gel electrophoresis, with $\mathrm{pH}$ 4-8 carrier ampholytes isoelectric focusing (IEF) as the first dimension and SDS polyacrylamide as the second dimension. The 2-D gels used in this study were run at the Department of Pediatrics, the University of Michigan, according to a procedure described previously. ${ }^{32}$

\section{Gel staining}

After separation of proteins from Esophageal Adenocarcinoma and Thymocyte cells by 2-D gel electrophoresis, the gels were stained with either Coomassie Blue R-250 or zinc negative staining. If Coomassie Blue staining was used, gels were fixed with $5 \%$ acetic acid and $50 \%$ ethanol for two hours, then stained with 1\% Coomassie Blue R-250, 10\% acetic acid, 40\% methanol for 30 min and destained with $10 \%$ acetic acid, $40 \%$ methanol for $30 \mathrm{~min}$. The zinc staining method was used to avoid interference of the dye $\mathrm{e}^{33}$ in the analysis. Gels were first equilibrated in $1 \% \mathrm{Na}_{2} \mathrm{CO}_{3}$ solution for $5 \mathrm{~min}$, stained with $200 \mathrm{mM}$ imidazole, $0.1 \%$ SDS for $15 \mathrm{~min}$, washed with deionized water for $1 \mathrm{~min}$ and

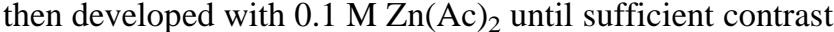
was obtained. The gels were rinsed with water three times before gels were destained with $1 \%$ citric acid twice for 20 min by vortexing.

\section{In-gel digestion}

The digestion procedure basically follows that of Williams et al.,${ }^{34}$ but with some modifications. Gel spots were cut into $0.5 \times 0.5 \mathrm{~mm}$ pieces and washed with buffer $\mathrm{B}(50 \%$ $\mathrm{CH}_{3} \mathrm{CN}, 50 \% 100 \mathrm{mM} \mathrm{NH}_{3} \mathrm{HCO}_{3}$ ) twice for $30 \mathrm{~min}$. After removing the washing buffer, gel pieces were covered with buffer B and $45 \mathrm{mM}$ dithiothreitol (DTT) was then added to bring the final concentration to $1 \mathrm{mM}$. Reduction was complete after $20 \mathrm{~min}$ incubation at $37^{\circ} \mathrm{C}$. Twice the volume (as compared to the volume of $45 \mathrm{mM}$ DTT added) of $100 \mathrm{mM}$ iodoacetamide was added and the pieces were incubated for $40 \mathrm{~min}$ at $37^{\circ} \mathrm{C}$ for the alkylation. After the supernatant had been removed, the gel pieces were washed again with buffer B for 30 min once and then twice for 15 min all with vortexing. After washing, the gel pieces were dried under speedvacuum for $20 \mathrm{~min}$. In order to perform digestion, $10 \mu \mathrm{L}$ aliquots of trypsin solution (1$2 \mu \mathrm{g}$ in $100 \mathrm{mM} \mathrm{NH} \mathrm{NHCO}_{3}$ ) were gradually added to the dried gel pieces until they were fully swollen, and more digestion buffer was added to sufficiently cover them. Digestion was performed at $37^{\circ} \mathrm{C}$ for $24 \mathrm{hr}$. After digestion, the peptides were extracted with $1 \%$ trifluoroacetic acid (TFA), $60 \% \mathrm{CH}_{3} \mathrm{CN}$ by sonication three times for $30 \mathrm{~min}$. The combined extracts were dried by speedvac.

\section{Solid phase extraction}

The digests were restored with $10 \mu \mathrm{L} 0.1 \%$ TFA and cleaned using ZipTip $_{\mathrm{C} 18}$ from Millipore. ${ }^{35}$ A ZipTip is a $10 \mu \mathrm{L}$ pipette tip packed with approximately a half microliter of silica $\mathrm{C}_{18}$. Briefly, the ZipTip was first wet with $50 \%$ acetonitrile/ $\mathrm{H}_{2} \mathrm{O}$ and equilibrated with $0.1 \%$ TFA. The protein digests were bound to the ZipTip by aspirating and dispensing the sample for 10 cycles. The remaining liquid was dispensed to waste. The tip was washed with buffer $\left(0.1 \% \mathrm{TFA} / \mathrm{H}_{2} \mathrm{O}\right)$ and was dispensed to waste. Elution was achieved with $4 \mu \mathrm{L}$ of $0.1 \%$ TFA/ $60 \%$ acetonitrile/ $\mathrm{H}_{2} \mathrm{O}$ by aspirating and dispensing the eluant through the tip four times. The eluate was dried under speedvacuum again and dissolved in $4 \mu \mathrm{L}$ of deionized water.

\section{On-line sheathless CE/MS system}

The digests were separated using a capillary electrophoresis apparatus constructed in-house, which includes a $30 \mathrm{kV}$ high voltage power supply (model CZE 1000R, Spellman High Voltage Electronics Corp., Plainview, NY, USA) and a Polybrene (positive) coated capillary column (37 $\mu \mathrm{m}$ i.d.) prepared according to the procedure of $\mathrm{Li}^{36}$ The detector used was an ion trap storage reflectron time-of-flight (IT/ reTOF) mass spectrometer described in previous work. ${ }^{36,37}$ The apparatus consists of a quadrupole ion trap storage device (model 1251,R.M. Jordan Co., Grass Valley, CA, USA) interfaced to a reflectron TOF mass analyzer (model 


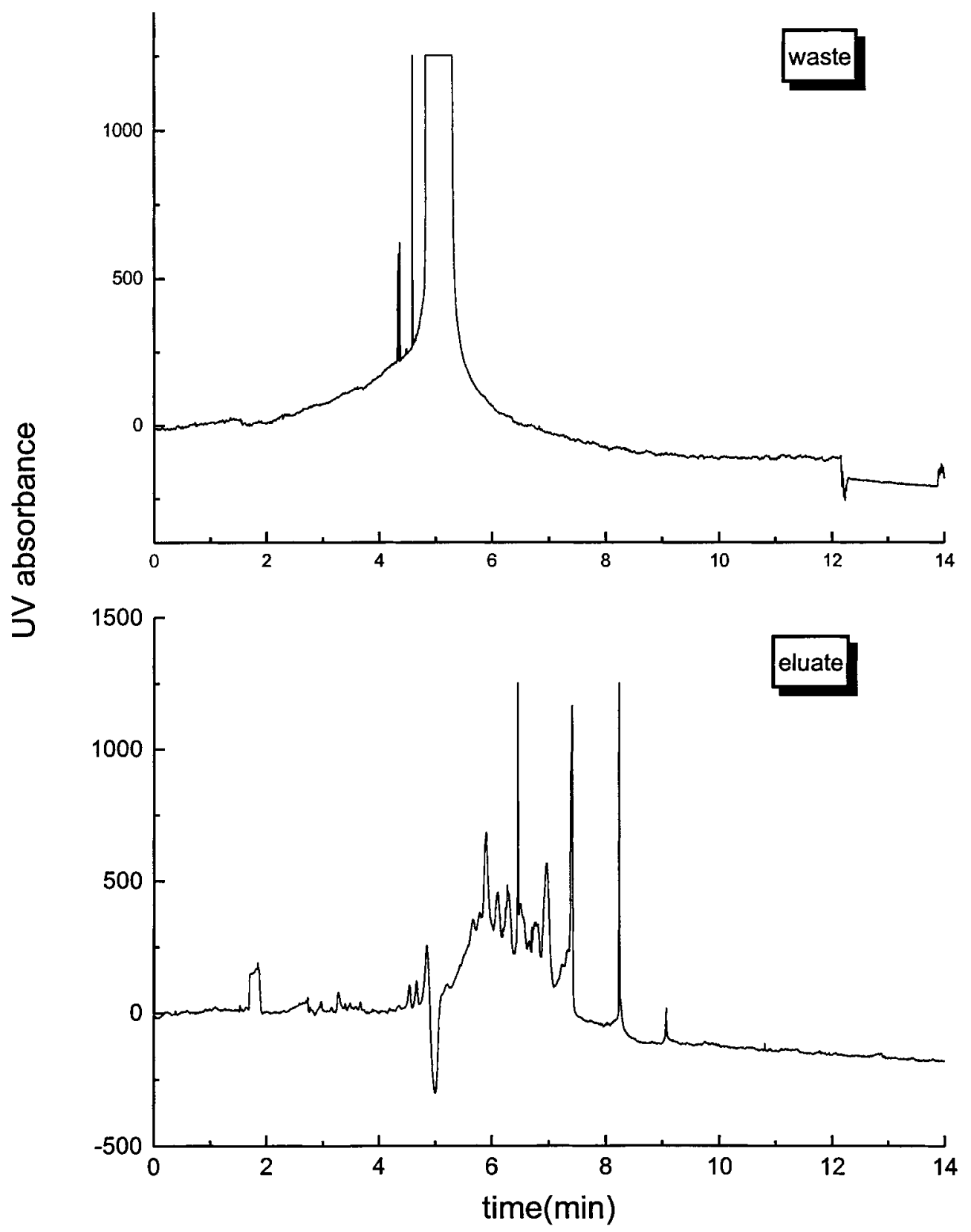

Figure 1. CE/UV electrophorograms of waste and eluate of tryptic digests of $\mathrm{C} 2$ after ZipTip cleanup. CE conditions: $70 \mathrm{~cm}$ long, $75 \mu \mathrm{m}$ i.d. fused capillary, injection: $8000 \mathrm{~V} \times 20 \mathrm{~s}$, separation: $26 \mathrm{kV}$.

D1450). Argon buffer gas (1 mTorr) was introduced into the ion trap to enhance the trapping. Detection was achieved using a $40 \mathrm{~mm}$ triple microchannel plate (MCP) detector (Model C-2501, R.M. Jordan Co.).

The anodic end of the CE capillary was used as the sheathless microelectrospray tip. This configuration was achieved by coating the capillary tip with silver. ${ }^{38}$ Electrokinetic injection was performed with $5000 \mathrm{~V}$ for $20 \mathrm{~s}$. The power supply of the capillary electrospray was set at ca. $-12 \mathrm{kV}$, while the microelectrospray needle was set at $3 \mathrm{kV}$, so that the total voltage across the capillary was $-15 \mathrm{kV}$.

The mass data were collected and processed using a $250 \mathrm{MHz}$ transient recorder (Model 9846, Precision Instruments Inc., Knoxville, TN, USA) connected to a Dell Pentium II $400 \mathrm{Mz}$ processor. Data analysis was accomplished using custom 2-D false color image software as described in previous work, with the $m / z$ spectrum on one axis, TIE elution time as the other axis and $m / z$ intensity as the image color. ${ }^{39}$ A cursor on this image map (or on the mass spectra and TIE plot) could be used to display the corresponding individual $\mathrm{m} / \mathrm{z}$ spectrum on the $\mathrm{x}$-axis and also integrate multiple spectra over an elution time range to increase the signal-to-noise $(\mathrm{S} / \mathrm{N})$ ratio. This integration capability allowed peaks of low intensity to be identified.

\section{On-line CE/MS/MS}

On-line CE/MS/MS with stored waveform inversed Fourier transform (SWIFT) technology has been developed in the ion trap reflectron time-of-flight mass spectrometer. ${ }^{40}$ Briefly, as a peak elutes it is detected and digitized by a PI9845 digitizer board in the computer. The computer interacts with an arbitrary waveform generator board 

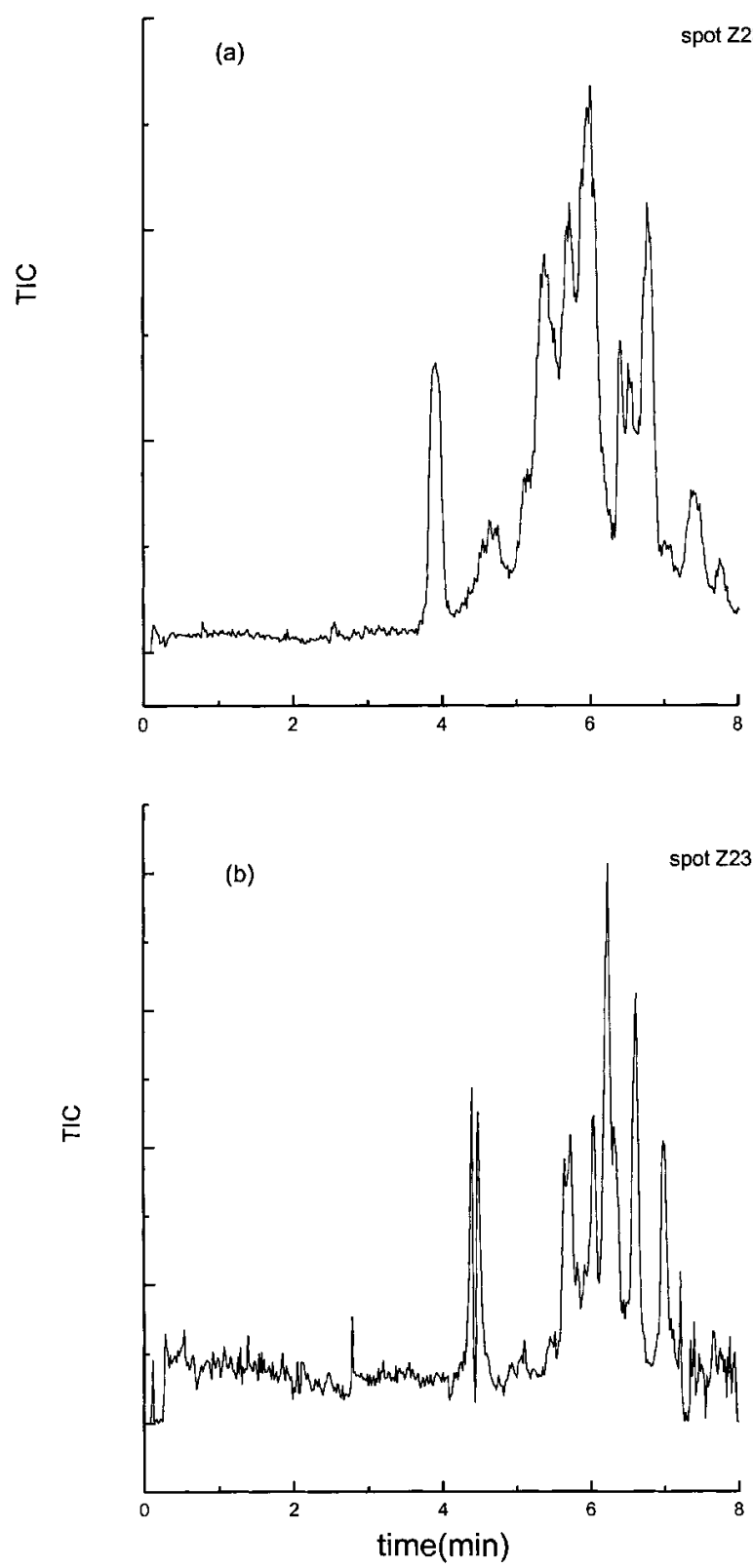

Figure 2. CE/TIC of tryptic digests of spot Z23 with capillaries of (a) $75 \mu \mathrm{m}$ i.d. (b) $37 \mu \mathrm{m}$ i.d. Injection: $5000 \mathrm{~V} \times 20$ s, separation: $300 \mathrm{~V} /$ $\mathrm{cm}$.

(AWGB) (model WSB-100-10, Quatech, Akron, OH, USA) which creates a notch in the frequency domain and parent ions are isolated and accumulated in the ion trap while other ions are ejected out of the ion trap. A TICKLE waveform is applied to induce the collision between the parent ions and buffer gas ions. Fragment ions are ejected by a DC pulse and detected by a reflectron TOF mass spectrometer. The TICKLE voltage is optimized on-line and MS/MS spectra are achieved at a sampling rate of $4 \mathrm{~Hz}$. MS/MS can be achieved at a sampling rate up to $8 \mathrm{~Hz}^{40}$ at a compromise of the $\mathrm{S} / \mathrm{N}$ of the spectrum; $4 \mathrm{~Hz}$ was chosen in this work as the best compromise between the speed of MS/MS acquisition and the quality of the mass spectra. The sequence of events for acquiring a single MS/MS spectrum and the timing of these events on the ion trap instrument using SWIFT and TICKLE waveforms and corresponding waveform time scales for each event at a $4 \mathrm{~Hz}$ rate, as used in this work, include: (1) Accumulate ions in the trap (136 ms). (2) Stop (a)

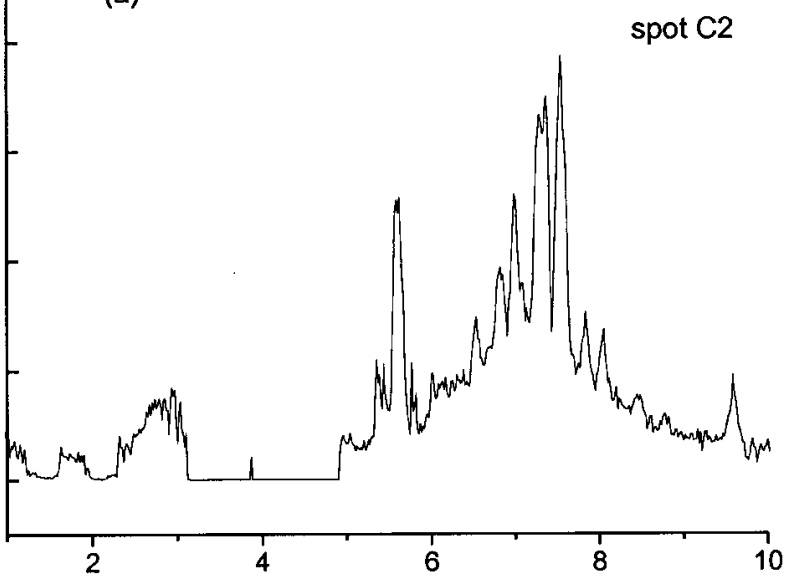

(b)

spot C3

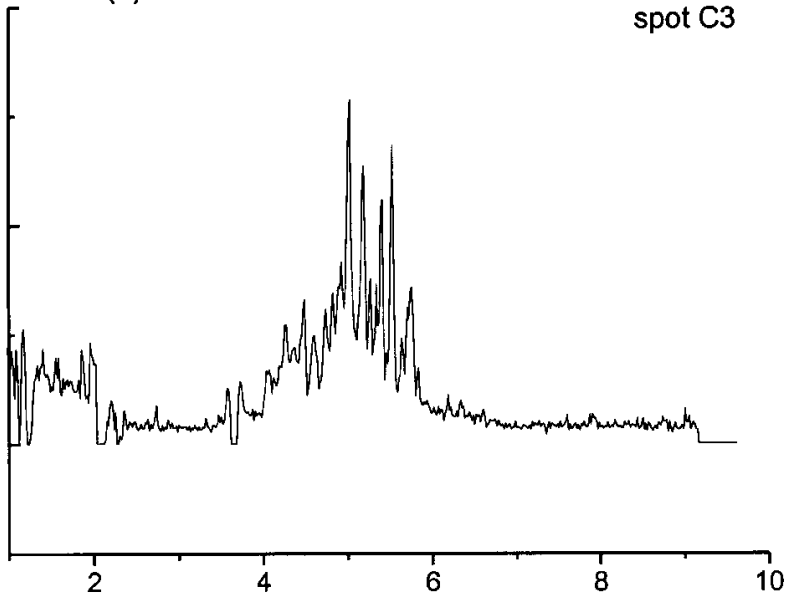

(c)

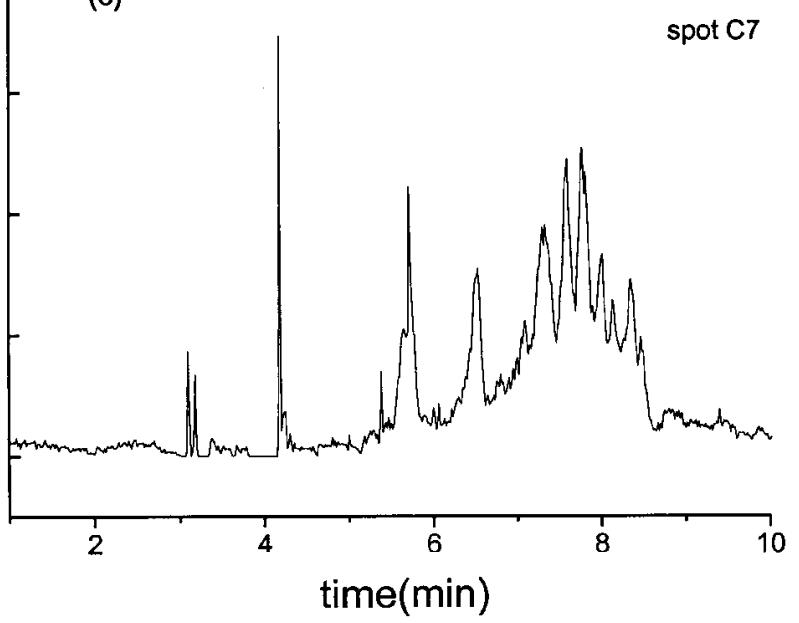

Figure 3. CE/TICs of tryptic digests of three identified proteins from Coomassie Blue stained gel (a) spots C2, (b) spots C3 and (c) spots C7. Injection: $5000 \mathrm{~V} \times 20 \mathrm{~s}$, separation: $3000 \mathrm{~V} / \mathrm{cm}$.

ions from entering the trap using an ion gating voltage. (3) Apply the SWIFT isolation waveform (32 ms). (4) Cool (25 ms). (5) Apply the TICKLE activation waveform (32 ms). (6) Cool (25 ms). (7) Eject ions from the trap. (8) Digitize the mass spectra. (9) Permit ions to begin accumulating in the trap again. (10) Transfer digitized data 


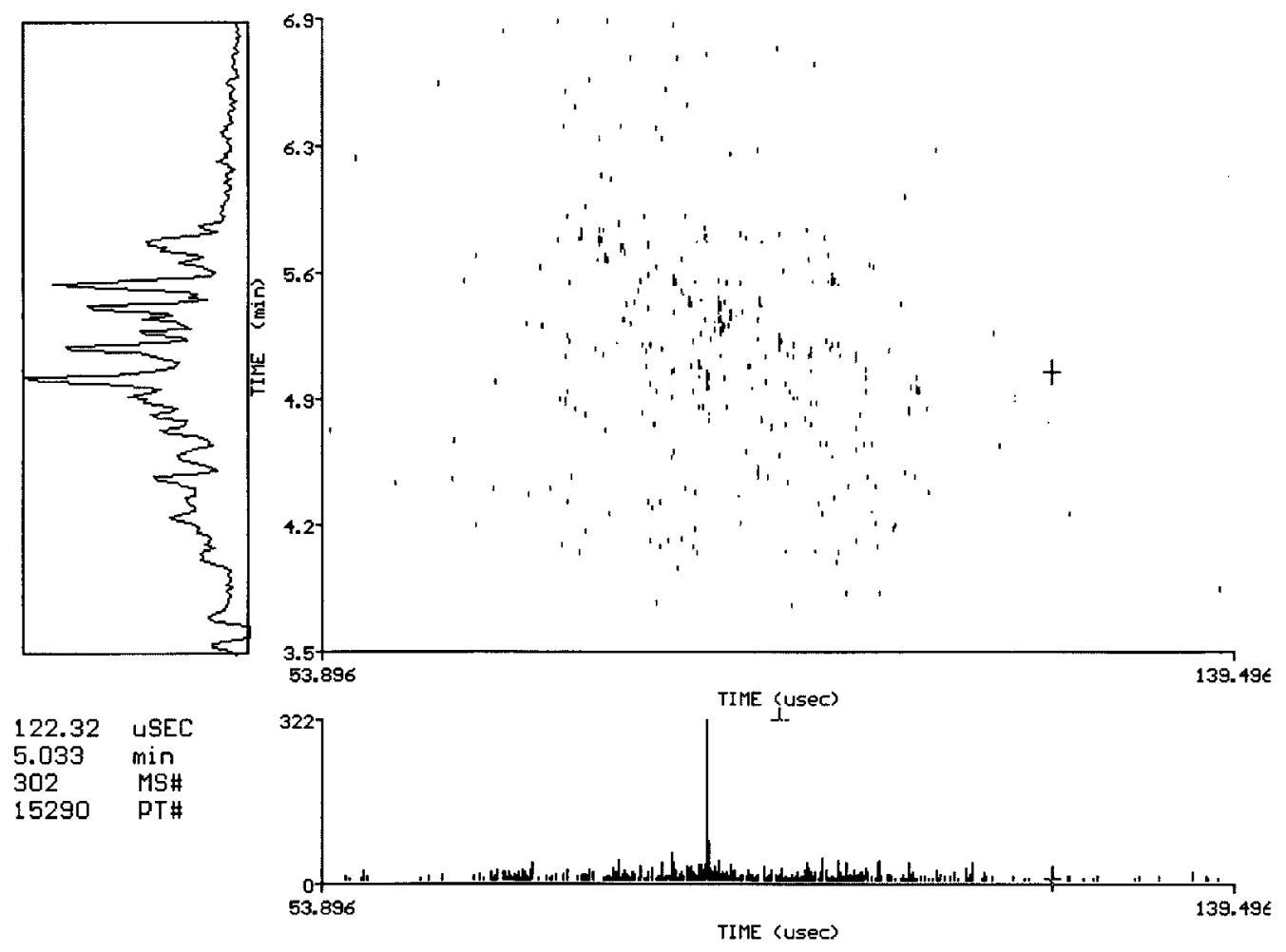

Figure 4. 2-D false color map of tryptic digests of $C 3$. The $x$-axis is flight time and $y$-axis is CE elution time.

to the computer. (11) Save mass spectra data in the computer. (12) Analyze mass spectra to determine appropriate TICKLE voltage to apply on the next cycle.

\section{RESULTS AND DISCUSSION}

\section{Method development}

The use of CE/MS as a method for analyzing complex sample mixtures often encounters the two problems of sample cleanup and concentration limit of detection (CLOD). In order to overcome these problems, previous work has been performed with on-line coupling of solid phase extraction (SPE) ${ }^{16,31}$ or membrane preconcentration to on-line CE/MS. ${ }^{30}$ Although on-line SPE/CE/MS has high sensitivity and sample recovery, the heterogeneity of the SPE/CZE coupling and the use of organic solvents for eluting the material may result in deterioration of the $\mathrm{CE}$ separation. Thus, we have investigated the CE/MS of gelseparated protein digests using an off-line SPE procedure for sample cleanup and preconcentration.

The digests of gel-separated proteins always contain salts, detergents, water-soluble polymers and tiny gel particles. If the sample is not purified before injection into the $\mathrm{CE}$ capillary, the capillary can be easily clogged and the separation degraded where contaminants may suppress the various peaks in mass spectrometric detection. In other work, HPLC has been used to clean and separate protein digests from gels since LC is more tolerant toward salts and detergents compared with CE. ${ }^{41}$ Thus in this work SPE is used to clean the protein digests obtained from 2-D gels. The ZipTip is used because it contains a microliter bed of $\mathrm{C}_{18}$ absorbent which leads to improved sample recovery. Figure 1 shows the CE/UV electrophorograms of eluate and

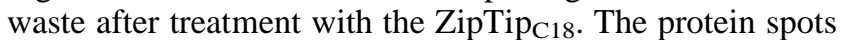
used were cut from 2-D gels of an Esophageal Adenocarci- noma cell line stained with Coomassie Blue. The i.d. of the capillary was $75 \mu \mathrm{m}$ and the sample was injected with $8000 \mathrm{~V}$ for $20 \mathrm{~s}$. In order to improve the separation with relatively large amounts of injected material, an on-line stacking technique was used. After sample injection, $50 \mathrm{mM}$ $\mathrm{NH}_{4} \mathrm{OH}$ was injected with $8000 \mathrm{~V}$ for $10 \mathrm{~s}$ and then separation was completed with $-26 \mathrm{kV}$. The CE separation of the waste material (Fig. 1(a)) contains a large saturated peak eluting around 4-6 min, while CE of the eluate (Fig. 1(b)) contains the peptide peaks which elute after $4 \mathrm{~min}$. If the sample is not cleaned before CE separation, contaminants and peptide peaks overlap and the signal is suppressed.

A narrower capillary (37 $\mu \mathrm{m}$ i.d.) was used to replace the $75 \mu \mathrm{m}$ i.d. capillary column to improve the separation. The amount of sample introduced by electrokinetic injection into a $37 \mu \mathrm{m}$ i.d. capillary is only one quarter that of the sample injected into a $75 \mu \mathrm{m}$ i.d. column under the same conditions. Figure 2 shows the separation of Spot Z23 from a Thymocyte cell with negative zinc staining by capillaries of two different diameters. The CE separation with $37 \mu \mathrm{m}$ i.d. provides much improved results compared with the separation with $75 \mu \mathrm{m}$ i.d., while peak intensities were still sufficiently strong for identification of proteins. Decreasing the amount of sample injected and increasing the separation voltage also improved the $\mathrm{CE}$ separation. The use of a $37 \mu \mathrm{m}$ i.d. capillary provides sufficient sensitivity to analyze protein digests from 2-D gels with improved separation.

Figure 3 shows the CE/TIE of spots C2, C3, C7 and Fig. 4 shows a 2-D false color image map of protein spot C3. The protein spots from eight pieces of gel which were obtained from eight 2-D gels run simultaneously were combined to perform digestion for CE/MS analysis. Each spot from the gel of C2 was estimated to contain 0.5-1 picomole before in-gel digestion. The digests was dissolved in $4 \mu \mathrm{L}$ of the 


\begin{tabular}{|c|c|c|c|c|c|c|}
\hline Spot & Protein identified & Acc\# & MW kDa & PI & Sequence coverage & Considering modification? \\
\hline \multirow[t]{2}{*}{$\mathrm{C} 2$} & HSP-60 & P10809 & 61055 & 5.7 & $54 \%$ & yes \\
\hline & & & & & $46 \%$ & no \\
\hline \multirow[t]{2}{*}{$\mathrm{C} 3$} & Actin, Cytoplasmic 1,2 & $\mathrm{P} 02570 / \mathrm{P} 02571$ & 41737 & 5.29 & $44 \%$ & yes \\
\hline & & & & & $38 \%$ & no \\
\hline \multirow[t]{2}{*}{ C7 } & Adenosine kinase & P55263 & 37491 & 6.28 & $41 \%$ & yes \\
\hline & & & & & $41 \%$ & no \\
\hline \multirow[t]{2}{*}{ Z23 } & Tubulin beta-1Chain & P07437 & 49759 & 4.75 & $33 \%$ & yes \\
\hline & & & & & $19 \%$ & no \\
\hline
\end{tabular}

solution where more than $40 \mathrm{CE} / \mathrm{MS}$ experiments could be performed. It is estimated that around ten femtomoles of sample are injected on each CE/MS experiment where $\sim 20$ 30 nanoliters are injected on each run. However at least $2 \mu \mathrm{L}$ of the liquid must be available in the $0.5 \mathrm{~mL}$ microcentrifuge tube in order to perform the electrokinetic injection properly so that only half the sample is actually used. Since $\mathrm{CE} / \mathrm{MS}$ only consumes nanoliter amounts of sample, multiple experiments are possible, including on-line $\mathrm{CE} /$ MS/MS and, in principle, CE/MS/MS/MS which can be used to further confirm the identification of proteins and post-tranlational modifications of proteins obtained from 2D gels. It should be noted that we could perform analysis of even a single gel piece using this method; however, since eight gel pieces were available, the entire sample was used since it was much easier to handle the larger amounts of material. The original eight pieces of gel provide a maximum of 2-4 picomoles of material for analysis since half of the sample can be used. Since 40 injections with 10 femtomole per injection amount to 400 femtomoles, the losses involved are still substantial. Further procedures for enhancing recovery in the purification procedure will be required.

\section{Identification of proteins by database search combined with $\mathrm{CE} / \mathrm{MS} / \mathrm{MS}$ confirmation and analysis}

The peptide mass peaks obtained from the 2-D false color maps were used for the database search. The integration capability of the 2-D program allows for detection of weak

\begin{tabular}{|c|c|c|c|c|c|}
\hline Spot & $\begin{array}{l}\text { Considering } \\
\text { modification? }\end{array}$ & Rank & MOWSE score & $\begin{array}{c}\#(\%) \text { Masses } \\
\text { matched }\end{array}$ & $\begin{array}{c}\text { Swiss-Prot } \\
\text { Acc\# }\end{array}$ \\
\hline \multirow[t]{2}{*}{$\mathrm{C} 2$} & Yes & 1 & $4.67 \mathrm{E}+07$ & $43 / 51(88 \%)$ & P10809 \\
\hline & No & 1 & $1.43 E+08$ & $34 / 51(66 \%)$ & P10809 \\
\hline \multirow[t]{5}{*}{$\mathrm{C} 3$} & Yes & 1 & $5.57 \mathrm{E}+03$ & $17 / 26(65 \%)$ & P02570 \\
\hline & & 2 & $5.56 \mathrm{E}+03$ & $17 / 26(65 \%)$ & $\mathrm{P} 02571$ \\
\hline & & 3 & 791 & $12 / 26(46 \%)$ & P12718 \\
\hline & No & 1 & $1.09 \mathrm{E}+04$ & $10 / 26(38 \%)$ & $\mathrm{P} 02570$ \\
\hline & & 2 & $1.09 \mathrm{E}+04$ & $10 / 26(38 \%)$ & P02571 \\
\hline \multirow[t]{4}{*}{$\mathrm{C} 7$} & Yes & 1 & $1.17 \mathrm{E}+06$ & $19 / 44(43 \%)$ & P55263 \\
\hline & & 2 & $1.73 E+03$ & $16 / 44(36 \%)$ & P48775 \\
\hline & & 3 & 193 & $15 / 44(34 \%)$ & P14550 \\
\hline & No & 1 & $4.86 \mathrm{E}+05$ & $14 / 44(31 \%)$ & P55263 \\
\hline \multirow[t]{4}{*}{ Z23 } & Yes & 1 & $2.15 \mathrm{E}+04$ & $21 / 35(60 \%)$ & P07437 \\
\hline & & 2 & $5.80 \mathrm{E}+03$ & $21 / 35(60 \%)$ & P05217 \\
\hline & & 3 & $1.53 \mathrm{E}+03$ & $18 / 35(60 \%)$ & P04350 \\
\hline & No & 1 & $3.21 \mathrm{E}+03$ & $10 / 35(28 \%)$ & P07437 \\
\hline
\end{tabular}

peptide peaks. MS-FIT created by UC San Francisco was chosen as the search engine because MS-FIT combines pI range, MW range, potential modifications, minimum matching peptide number and other features. The searching results with and without modification were compared. The modifications considered here include oxidation of methionine and peptide N-terminal Gln to pyro-Glu. The search can be performed in different protein databases. SWISSPROT and NCBInr are two major databases used for the protein search.

Table 1 lists four proteins identified by CE/MS. The spots C2, C3 and C7 were cut from Coomassie Blue stained 2-D gel separations of an Esophageal Adenocarcinoma cell line, while Z23 is from a 2-D gel separation of zinc negatively stained Thymocyte cells. It was found that performing database searching without considering possible modifications results in a lower peptide matching percentage; however, it generally provides one good match, as shown in Table 2. In the case of database searching with modifications considered, slightly lower MOWSE scores were obtained for samples $\mathrm{C} 2$ and $\mathrm{C} 3$ as compared with the case of $\mathrm{C} 7$ and $\mathrm{Z23}$, where database searching with modifications increased the MOWSE score compared with those with no modification considered. It should be noted that there are two kinds of peptide match: scoring matches and non-scoring matches. Scoring matches include unmodified peptides and acrylamide modified cysteine and $\mathrm{N}$ terminal glutamine to pyro-Glu and oxidation of methionine in the presence of the unmodified peptide. Non-scoring matches include pyro-Glu and oxidation of methionine in the absence of the unmodified peptide, acetylated $\mathrm{N}$ terminal, phosphorylation of $\mathrm{S}, \mathrm{T}$ and $\mathrm{Y}$ and single amino substitutions. In computing the MOWSE score unmatched masses are ignored. In the case of multiple matching masses the scores are multiplied together. The final MOSWE score is normalised to an average protein molecular weight of 50 $\mathrm{kD}^{42}$

C2 has been identified as HSP 60. A high matching percentage and MOWSE score are obtained for this sample. Spot $\mathrm{C} 3$ has been identified as actin, $\beta$ or $\gamma$ chain, where the major difference between the $\beta$ and $\gamma$ chain is in the first tryptic fragment. We did not detect the first fragment, so we were unable to differentiate between these two proteins. Many parameters in the in-gel digestion and SPE procedure affect the peptide recovery. It is possible that some hydrophilic peptides are lost during the washing procedure. In order to improve peptide recovery, mixed absorbents have been used by one group. ${ }^{4} \mathrm{C} 7$ has been identified as adenosine kinase. $\mathrm{Z} 23$ has been identified as tubulin beta- 1 chain.

Database searching in different databases will provide different results. In this case, a comparison between such 

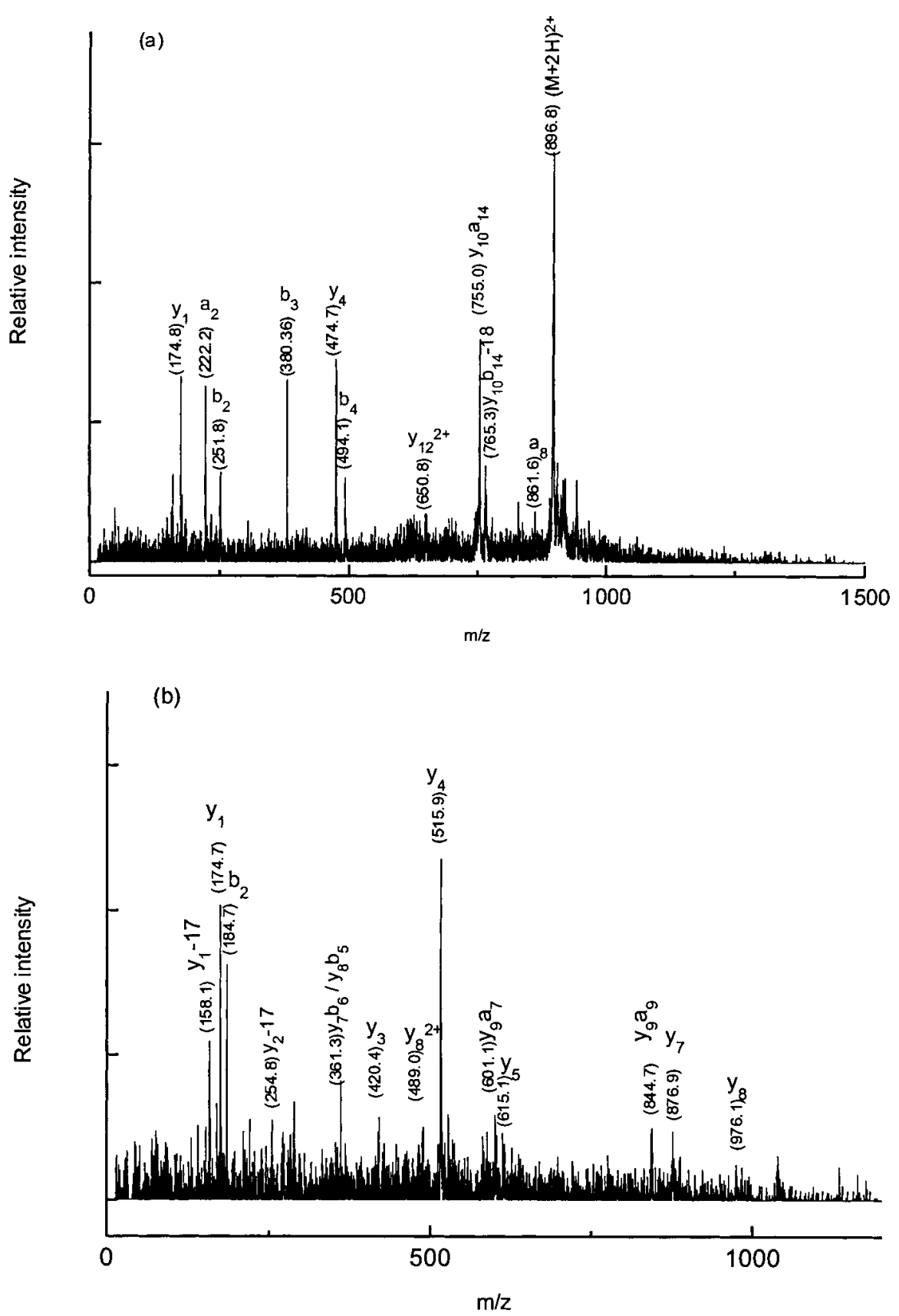

Figure 5. CID spectra of two peaks chosen from tryptic digests of (a) spots $\mathrm{C} 3, \mathrm{~m} / \mathrm{z}$ of parent ion 895.67, sequence SYELPDGQVITIGNER and (b) spots Z23, $\mathrm{m} / \mathrm{z}$ of parent ion 580.58 , sequence LAVNMVPFPR where $M$ is oxidized.

results must be cautiously analyzed. In order to confirm the identification, tandem mass spectrometry is required. Because CE/MS only consumes nanoliters of sample per run, detailed information concerning post-translational modification of proteins can be obtained by CE/MS/MS. $\mathrm{CE} / \mathrm{MS} / \mathrm{MS}$ confirmed spot $\mathrm{C} 3$ as actin and $\mathrm{Z} 23$ as tubulin beta-1 chain. The collision induced dissociation (CID) spectra are shown in Fig. 5. The CID spectrum of parent ion 895.67 from C3 matched the sequence SYELPDGQVITIGNER, though the $\mathrm{m} / \mathrm{z}$ of the sequence MQKEITALAPSTMKIK is similar to that of the parent ion too. Figure 5(b) shows the CID spectrum selected from the CE/MS mapping of the $\mathrm{Z} 23$ tryptic digest. The sequence is LAVNMVPFPR where methionine is oxidized.

\section{CONCLUSIONS}

Capillary electrophoresis/TOFMS has been used for the analysis of in-gel digests of protein spots separated by 2-D SDS-PAGE. The method was capable of analyzing spots from Coomassie Blue stained gels and zinc negatively stained gels where less than 1 picomole of material may be available for analysis. An off-line purification and preconcentration procedure using a ZipTip was used before $\mathrm{CE} / \mathrm{TOF}$ mass spectrometric analysis for purification of the sample from detergents and salts and to achieve a concentration level allowing detection of the peptide digest products from gels. This off-line method was used since it provided sufficient purification of the sample while 
maintaining the quality of the $\mathrm{CE}$ separation. The $\mathrm{CE} /$ TOFMS method was used to identify actual protein spots from 2-D gels in the $\mathrm{m} / \mathrm{z}$ range from 40 to $60 \mathrm{kDa}$ using peptide maps and database searching. The ion trap was used to perform tandem mass spectrometry on selected peptides to pinpoint the presence of modifications.

\section{Acknowledgements}

The authors gratefully acknowledge support of this work by the National Institutes of Health under grant No. 2-R01GM49500-5 and the National Science Foundation under grant No. BIR-9513878.

\section{REFERENCES}

1. Ducret A, vanOostveen I, Eng JK, Yates JR, Aebersold R. Protein Science 1998; 7: 706

2. Courchesne PL, Jones MD, Robinson JH, Spahr CS, McCracken S, Bentley DL, Luethy R, Patterson SD. Electrophoresis 1998; 19: 956.

3. Wilm M, Shevchenko A, Houthaeve T, Breit S, Schweigerer L, Fotsis T, Mann M. Nature 1996; 379: 466.

4. Neubauer G, Mann M. Anal. Chem. 1999; 71: 235.

5. Zugaro LM, Reid GE, Ji H, Eddes JS, Murphy AC, Burgess AW, Simpson RJ. Electrophoresis 1998; 19: 867.

6. Reid GE, Rasmussen RK, Dorow DS, Simpson RJ. Electrophoresis 1998; 19: 946

7. Henzel JW, Billeci TM, Stults JT, Wong SC, Grimely C, Watanabe C. Proc. Nat. Acad. Sci. 1993; 90: 5011.

8. Williams K, LoPresti M, Stone K. Internal Protein Sequencing of SDS-PAGE Separated Proteins: Optimization of In-Gel Digest Protocol, In Techniques in Protein Chemistry VIII, Marshak D (ed). Academic Press, 1997.

9. Eckerskorn C, Grimm R. Electrophoresis 1996; 17: 899.

10. Rosenfeld J, Capdevielle J, Guillemot JC, Ferrara P. Anal. Biochem. 1992; 203: 173.

11. Li G, Waltham M, Anderson NL, Unsworth E, Treston A Weinstein JN. Electrophoresis 1997; 18: 391.

12. Zhang WZ, Czernik AJ, Yungwirth T, Aebersold R, Chait BT. Protein Science 1994; 3: 677.

13. Loo RO, Stevenson TI, Mitchell C, Loo JA, Andrews PC. Anal. Chem. 1996; 68: 1910 .

14. Mann M, Wilm M. Anal. Chem. 1994; 66: 4390.

15. Yates JR, III. Eng JK, McCormack AL, Schieltz D. Anal. Chem. 1995; 67: 1426.

16. Figeys D, Ducruet A, Yates JR, Aebersold R. Nature Biotech. 1996; 14: 1579 .

17. Davis MT, Lee TD. J. Am. Soc. Mass Spectrom. 1998; 9: 194.
18. Fang L, Zhang R, Williams ER, Zare RN. Anal. Chem. 1994; 66: 3696.

19. Muddiman DC, Rockwood AL, Gao Q, Severs JC, Udseth HR, Smith RD. Anal. Chem. 1995; 67: 4371.

20. Banks JF, Dresch T. Anal. Chem. 1996; 68: 1480.

21. Lazar JM, Xin B, Lee ML, Rockwood AL, Fabbi JC, Lee HG. Anal. Chem. 1997; 69: 3205.

22. Hsieh F, Baronas E, Muir C, Martin SA. Rapid Commun. Mass Spectrom. 1997; 13: 67.

23. Mccomb ME, Krutchinsky AN, Standing KG, Perreault H. J. Chromatogr. A. 1998; 800: 1

24. Palmer ME, Clench MR, Telter LW, Little DR. Rapid Commun. Mass Spectrom. 1997; 13: 256.

25. Thompson TJ, Foret F, Vouros P, Karger BL. Anal. Chem. 1993; 65: 900.

26. Chien R-L, Burg DS. Anal. Chem. 1992; 64: 489A.

27. Albert M, Debusschere L, Demesmay C, Rocca JL. J. Chromatogr. A 1997; 757: 281.

28. Stegehuis DS, Tjaden UR, Van der Greef J. J. Chromatogr. 1992; 591: 341 .

29. Tomlinson AJ, Benson LM, Braddock WD, Oda RP, Naylor S. J. High Res. Chromatogr. 1995; 18: 381.

30. Qin J, Herring C. J. Rapid Commun. Mass Spectrom. 1999; 13: 1.

31. Petersson M, Wahlund K-G, Nilsson S. J. Chromatogr. A 1999; 841: 249.

32. Strahler JR, Kuick R, Hanash SM. Protein Structure: A Practical Approach. Creighton T. (ed). IRL Press Ltd; Oxford. 65-92.

33. Castellanos-Serra L, Proenza W, Huerta V, Moritz RL, Simpson RJ. Electrophoresis 1999; 20: 732.

34. Williams K, LoPresti M, Stone K. Internal Protein Sequencing of SDS-PAGE Separated Proteins: Optimization of In-Gel Digest Protocol; In Techniques in Protein Chemistry VIII, Marshak D (ed) Academic Press, 1997.

35. Hornshaw MP, Parker KC, Sheer DG. Proc. $46^{\text {th }}$ ASMS Conf. Mass Spectrometry and Allied Topics, 1998

36. Li MX, Liu L, Wu J-T, Lubman DM. Anal. Chem. 1997; 69: 2451.

37. Wu J-T, Qian MG, Li MX, Liu L, Lubman DM. Anal. Chem. 1996; 68: 3388 .

38. Mallory GO, Hajdu JB. Electroless Plating: Fundamentals and Applications; American Electroplaters and Surface Finishers Society.

39. Li MX, Wu J-T, Parus S, Lubman DM. J. Am. Soc. Mass Spectrom. 1998; 9: 701

40. Jin X, Kim J, Parus S, Zand R, Lubman DM. Anal. Chem. 1999; 71 3591.

41. Chen Y, Jin X, Misek D, Hinderer R, Hanash SM, Lubman DM. Rapid Commun. Mass Spectrom. 1999; 13: 1907.

42. Clasuer K, Baker P. MS-Fit instructions. Available: http:// prospector.ucsf.edu/ucsfhtml3.2/instruct/fitman.htm. 